New accelerators

Delay at Geneva

If you win some, you can afford to lose some. That seems to be the philosophy at CERN, the European centre for nuclear physics near Geneva. With a few intermediate vector bosons in the bag (see Nature 27 January, p.285), the laboratory seems now stoically to have accepted that its next big accelerator, LEP, will be a year late.

For years there has been pressure on CERN to build LEP quickly, and ahead of the competition in the United States. CERN director-general Professor Herwig Schopper last week told senior staff that because of problems in the approval procedure, LEP is likely to delayed by six months to a year.

LEP will be a giant underground ring, 27 $\mathrm{km}$ in circumference, of magnets and vacuum pipe designed to collide multiple bunches of electrons and positrons into one another at sufficient energy, intensity and frequency to produce copious numbers of intermediate vector bosons and other particles. The immediate competitor, the Stanford Linear Collider (SLC), has similar objectives but different means: electrons and positrons in single ultraintense and narrow bunches produced by the Stanford Linear Accelerator. These bunches will collide only once.

SLC is smaller and cheaper than LEP. According to Nobel prizewinner Burton Richer who is designing SLC, it will produce collisions in autumn 1986. LEP will not be ready for experiments until late 1988. But CERN staff expect SLC to face many technical difficulties. Although designed to produce as many as a quarter of the number of intermediate vector bosons as LEP, SLC may do little more than repeat the current low vector boson production rate at the CERN proton-antiproton collider.

Meanwhile, there is friction between the village of Echevenex, which has a major access pit rising in a local beauty spot overlooking the village, and CERN management. Villagers are not satisfied that the horizontal tunnel they requested would cost SF 27 million ( $£ 8.6$ million); their advisers say SF 15-17 million, compared with the total LEP cost of around SF 1,000 million ( $£ 320$ million). But the environmental commissioners accepted CERN's case that the tunnel was too expensive. The villagers are now attempting to block the approval procedure. Ultimately the prefect of the region can overrule them, but this takes time.

So, instead of final approval coming from the French constitutional court in the spring, as expected, it might not arrive before end of the year. But the drilling of the main LEP tunnel is the most timeconsuming part of LEP construction, so if the starting time is delayed, so is LEP.

Robert Walgate

US science travel

\section{Fulbright helps}

Washington

A CHANGE in the migratory pattern of US scientists seems to be discernible, but it is too soon to tell what it means. After some years of a falling trend of overseas visits by US scientists and engineers, applications for the Fulbright travel funds are now booming. So varied are the purposes of foreign travel, and the sources of funds therefor, that looking for national trends in the Fulbright data may be no better than reading tea-leaves. These, however, are the facts:

- Applications by and awards to graduate students for study in Western Europe have increased in the past three years. The Institute of International Education in New York, which administers the graduate student programme, says that awards increased from 30 in 1980-81 to 35 last year and 45 in the present academic year. Half of the students mainly in chemistry and biochemistry, opt for West Germany, with Switzerland ranking second.

- Applications for Fulbright travel and research awards from scholars seeking to visit France are dramatically up. The Council on International Education (responsible for this programme) says that it has already received 70 applications for visits to France, more than the number of awards last year.

- The United Kingdom remains one of the most popular destinations for US scholars, so that even though awards amount to only $\$ 500$ a month, only one in ten applications succeeds. The Council for International Exchange of scholars in Washington says that applications from scientists, especially biologists, are increasing. Graduate students face even longer odds, with 600 applications for the 30 Fulbright places awarded each year in the United Kingdom.

Those close to these programmes say that the changes which have taken place may be only blips on the chart. Interpretation of the data is in any case complicated by the way in which the Fulbright programmes vary from country to country: thus Austria picks only eight scholars, mostly scientists, but West Germany encourages scientists to apply for Humboldt Fellowships instead. Dr Dorothy S. Zinberg (Harvard), a student of international scientific travel (see Nature 295, $605 ; 1982$ ) says that a more systematic study of the trends is needed, and that people may be applying for Fulbright funds because other sources have dried up.

Deborah Shapley

\title{
Nature index of biotechnology stocks
}

\begin{tabular}{|c|c|c|c|c|c|}
\hline $\begin{array}{l}\text { 12-month } \\
\text { High }\end{array}$ & $\begin{array}{l}\text { 12-month } \\
\text { Low }\end{array}$ & Company & $\begin{array}{l}\text { Close } \\
\text { previous } \\
\text { month }\end{array}$ & $\begin{array}{l}\text { Close } \\
28 \text { Jan. }\end{array}$ & Change \\
\hline $53^{*}$ & $161 / 8$ & A.B. Fortia (Sweden) & $447 / 8$ & 49 & $+4 \frac{1}{s}$ \\
\hline 8 & 2 & Bio-Logicals (Canada) & $41 / 4$ & $33 / 4$ & $-1 / 2$ \\
\hline $103 / 4 *$ & $3 \frac{3}{8}$ & Bio-Response (USA) & $75 / 8$ & $10^{3 / 4} *$ & $+3 \frac{1}{8}$ \\
\hline $14^{3 / 8} *$ & $73 / 4$ & Cetus (USA) & $12^{3 / 3}$ & $14^{3} / 8 *$ & +2 \\
\hline $12 \%$ * & $61 / 8$ & Collaborative Research (USA) & $11^{7 / 8}$ & $12^{5} / 8 *$ & $+3 / 4$ \\
\hline $20^{*}$ & $53 / 4$ & Damon (USA) & $16^{1 / 8}$ & $193 / 4$ & $+3 \frac{5}{8}$ \\
\hline 28* & $81 / 4$ & Enzo-Biochem (USA) & $261 / 2$ & $28^{*}$ & $+11 / 2$ \\
\hline 28 & $6^{5 / 8}$ & Flow General (USA) & $11^{7} / 8$ & $143 / 4$ & $+27 / 8$ \\
\hline $533 / 4 *$ & 26 & Genentech (USA) & $41 \frac{3 / 4}{3}$ & $533 / 4 *$ & +12 \\
\hline $121 / 2 *$ & $21 / 4$ & Genetic Systems (USA) & $81 / 2$ & 11 & $+21 / 2$ \\
\hline $1: 3 / 8 *$ & 7 & Genex (USA) & $12^{7 / 8}$ & $16^{3 / 4}$ & $+37 / 8$ \\
\hline $273 / 4$ & $95 / 8$ & Hybritch (USA) & $221 / 4$ & $261 / 4$ & +4 \\
\hline $16^{3 / 4} *$ & 5 & Molecular Genetics (USA) & $143 / 4$ & 14 & $-3 / 4$ \\
\hline 52 & $34^{7} / 8$ & Novo Industri $\mathbf{A} / \mathbf{S}$ (Denmark) & $43^{7} / 8$ & $493 / 4$ & $+5 \%$ \\
\hline 27 & 8 & Monoclonal Antibodies (USA) & $201 / 2$ & $191 / 2$ & -1 \\
\hline
\end{tabular}

The Nature Biotechnology Index for January 1983, stands at 181.7 compared with $\mathbf{1 5 7 . 5}$ for December 1982. Base is 100 as of 25 June 1982. The previous index appeared in Nature 13 January, p.105. Where stocks are traded over the counter, the price quoted is the bid price. Where stocks are traded on the American and New York stock exchanges, the price quoted is the transaction price. Yearly highs and lows are based on Friday closing prices.

*New high or low price.

IN January, Nature's index of biotechnology stocks scored its biggest single gain since its formation last June. The follow on rise reflects the continuing interest of large investors such as institutional endowment funds and the decline of the US dollar in January against the Swedish and Danish kroner. This made the stock of the two largest companies in the Nature index, A.B. Fortia and Denmark's Novo Industri, especially attractive to US investors.
Another factor was Genentech's stock, which moved upwards sharply in midJanuary after the company held a meeting for a hundred securities analysts at its headquarters in south San Francisco. Smaller companies have also been doing well in the stock market lately; the stock of Enzo-Biochem of New York, which traded at around 14 before the market surged in October, closed at 28 on 28 January.

Deborah Shapley 